\title{
Consumindo o candomblé: estudo sobre a comunicação dos objetos dessacralizados e trocas sígnicas na pós-modernidade
}

\author{
Cristiano Henrique Ribeiro dos Santos ${ }^{1}$ \\ UFRJ \\ cristiano.henrique@gmail.com
}

\begin{abstract}
Resumo: Este artigo analisa as Religiões Afro-Brasileiras nas perspectivas das teorias do consumo e da historicidade do mercado neste universo de relações mágico-religiosas. Sendo assim, as questões refletidas se inserem $e$ são inseridas na cultura de consumo, relacionando-se a seita com a expansão da produção capitalista de mercadorias. São estudados tanto os aspectos que se manifestam pela lógica do consumo endógeno (no interior do culto, no consumo ritual) quanto exógeno (na externalidade do culto, pelo consumo das imagens e signos, fora da religiosidade, pelos não-praticantes). Na dinâmica do consumo de produtos da diversidade cultural na pós-modernidade, o objeto de análise passa pela inserção do Candomblé como fonte da produção de bens simbólicos e materiais na indústria da moda e do entretenimento, dentre outras indústrias culturais.
\end{abstract}

Palavras-chaves: Candomblé, Comunicação e Teorias do Consumo, Sistemas de Significação.

\begin{abstract}
This article analyses the Afro-Brazilian Religions under the consumption theory and the market historicity in this universe of magicreligious relations. This way, the reflected questions are inserted in the consumption culture, relating to the sect with the spread of the capitalist production of goods. The aspects shown by the endogenous consumption logic (inside the cult, in the ritual consumption) as well as the exogenous ones (outside the cult, by the image and signs consumption, outside religiosity, by the people that do not carry it out) are studied. In the goods consumption dynamics of the cultural diversity in the post modernity, the analysis object goes through the insertion in Candomble as a production source of symbolic goods and material in the fashion and entertainment industry, among other cultural industries.
\end{abstract}

Key words: Candomblé, Communication and Consumption Theories, Signification Systems.

Résumé: Cet article analyse les Religions Afro-Brèsiliennes dans les perspectives des théories de consommation de l'histoire du marché dans cet univers des relations magiques-religieuses. Ceci dit, les questions réflechies sont insérées dans la culture de consommation, établissant la relation du culte

\footnotetext{
${ }^{1}$ Doutorando e Mestre em Comunicação e Cultura pela Escola de Comunicação da UFRJ e Pesquisador do Laboratório de Estudos em Comunicação Comunitária (LECC/UFRJ).
} 
avec l' expantion de la production capitaliste des marchandises. Sont alors étudiés les aspects qui se manifestent par la logique de la consommation endogène (à l'interieur du culte, la consommation rituelle) mais aussi de la consommation exogène (à l'exterieur du culte, par la consommation d'images et de signes en dehors de la religiosité, par les non-praticants). Dans la dynamique de la consommation de produits de la diversité culturelle de la pos-modernité, l'objet de l'analyse passe par l'insertion du Candomblé comme une source de production de biens symboliques et matériels dans l'industrie de la mode et de l'entretien, entre autres industries culturelles.

Mots Clefs: Candomblé, Comunication et Théories de Consomation, Systèmes de Signes.

Resumen: Este artículo analiza las Religiones Afro-Brasileñas en las perspectivas de las teorías del consumo e de la historicidad del mercado en este universo de relaciones mágico-religiosas. De esta manera, las cuestiones reflejadas se insertan e son inseridas en la cultura de consumo, relacionandose la secta con la expansión de la producción capitalista de mercancías. Son estudiados tanto los aspectos que se manifestan por la lógica del consumo endógeno (en el interior del culto, en el consumo ritual) quanto exógeno (en la externalidad del culto, por el consumo de las imágens e signos, fuera de la religiosidad, por los no practicantes). En la dinámica del consumo de productos de la diversidad cultural en la pos-modernidad, el objeto de análisis pasa por la inserción del Candomblé como fuente de la producción de haberes simbólicos e materiales en la industria de la moda e del entretenimiento, entre otras industrias culturales.

Palabras-llaves: Candomblé, Comunicación e Teorías del Consumo, Sistemas de Significación. 
No princípio era o mercado. No princípio e também por todo o sempre que veio depois. Base de um avanço e de um encontro, chão do homem já civilizado, nada supera o mercado como elemento aglutinador por excelência das comunidades que, heteromorfas mesmo quando unidas por interesses e idiomas comuns, precisam de pontos de reunião e de permutas, de entendimento eventual e de trocas de produtos. No princípio era o mercado e, através dele, aprendeu o homem a lidar com o outro, a respeitá-lo, em muitos casos a amá-lo, no sentido evangélico do verbo.

Antonio Olinto ${ }^{2}$

O Candomblé3 é um sistema mágico-religioso genuinamente brasileiro, constitui-se em expressão religiosa que se fundamenta numa cultura arcaica, antiga, oriunda da África. "Candomblé designa, atualmente, o culto dos deuses africanos, prestado em todo Brasil, segundo as tradições praticadas na Bahia" (Verger, 1992, p.96). O Candomblé apresenta-se nesta análise em sua perspectiva comunicacional e atual, em que está imerso na cultura informacional e pós-moderna, em que o seu centro se esvazia de sentido para inserir-se no mundo das imagens e do consumo. Neste estudo, o fundamento importa, configurando-se como marco conceitual e sentido ontológico, para que se entenda a passagem dos signos religiosos afrobrasileiros, da representação e encarnação do fundamento para a dimensão da produção de bens de consumo e do próprio consumo, bem como apropriação estética dos signos afro-brasileiros pela estética, pelo kitsch. Esta perspectiva demonstra que o Candomblé (ainda que seja calcado nos vínculos comunitários, na tradição e em valores arraigados em bases mítico-religiosas) apresenta-se também como um sistema cultural. Está estabelecido em relações não apenas subjetivas e transcendentais - como também bastante concretas e imanentes - , no que tange à sua inserção nos processos comunicacionais relacionados à lógica econômica da produção e da circulação capitalista de bens e serviços. Estas questões podem ser

\footnotetext{
2 Prefácio de BARROS, José Flávio Pessoa deet alli. A Galinha D’ Angola: Iniciação e Identidade na Cultura Afro-Brasileira. Rio de Janeiro: Pallas, 1993. p. 9.

3 Segundo verbete do Dicionário Eletrônico Houaiss da Língua Portuguesa, o Candomblé é uma religião “(...) original da região das atuais Nigéria e Benim [também de Angola], trazida para o Brasil e aqui estabelecida, talvez já no início do sXIX, por africanos apresados pelo tráfico escravagista, e na qual sacerdotes e adeptos encenam, em cerimônias públicas e privadas, uma convivência com forças da natureza e ancestrais.”
} 
vistas por transbordamentos, nas passagens de uma religião fortemente ligada ao local, aos territórios, para o mundo de relações estabelecidas em termos midiáticos, mercadológicos e virtuais.

No entanto, o aspecto mais relevante de tais observações refere-seà formação de uma "estruturação econômica" em torno dessa expressão religiosa, enquanto força geradora de uma rede de relações materiais e simbólicas. Desta forma, o caráter de "heterogeneidade atuante" demonstra-se fundamentalmente dinâmico, na medida em que essa "continuidade cultural" foi ampla o suficiente para que novas regras de relações de troca se constituíssem (Sodré, 1988, p.132-133). Assim, da imbricação das "diferenças" permitiu-se a formação de um complexo amálgama - tradição ${ }^{4}$ e modernidade -, que propiciou a estruturação de uma ordem própria, calcada em códigos particulares de linguagem e comunicação. Destarte, não se torna inviável a manutenção dos aspectos tradicionais do culto, sem perda de conexão com o tempo presente e com a dinâmica histórica, social e econômica.

Para propor uma relação entre Candomblé e cultura de consumo, deve-se tentar classificar alguns dos principais pontos de análise da questão: 1) O aspecto estrutural das relações de comércio e consumo material e cultural no Candomblé, em sua matriz africana; 2) O uso esotérico (hermético) dos signos do Candomblé (como objetos de consumo ritualreligioso); 3) O uso exotérico (vulgar) dos signos do Candomblé (como objetos de proteção ou amuletos, sem o sentido ritual primário); 4) O uso dos serviços religiosos - jogos de búzios e ebós (trabalhos e oferendas); 5) O Candomblé como espetáculo coletivo e de dimensão festiva sacroprofana; 6) O uso estético dos signos do Candomblé na moda - adorno e vestuário; 7) O Candomblé como fonte e inspiração da produção cultural - a produção acadêmica, a literária, os manuais de prática religiosa, a música e as artes plásticas; 8) O consumo telemático dos produtos e serviços oferecidos pelo Candomblé - canais telefônicos, televisuais e virtuais de comunicação e compra de produtos e oferta de serviços.

\footnotetext{
${ }_{4}^{4}$ Entenda-se tradição, no contexto aplicado, na acepção que a palavra possui na arkhé - tradição sem tradicionalismo. Ver SODRÉ. Claros e Escuros: Identidade, Povo e Mídia no Brasil. Petrópolis: Vozes, 1999. pp. 176-178.
} 
A análise dos aspectos estruturais das relações de comércio e consumo material e cultural no Candomblé deve partir de uma perspectiva que leve em conta a vida material e econômica do povo do Candomblé, em sua imbricação com a sociedade mais ampla. Para Braudel (p.16), a vida material se refere a tudo que a humanidade, no decorrer de sua história, “(...) foi incorporando na sua vida profunda e nas próprias entranhas dos homens, para quem tais experiências ou intoxicações antigas se tornaram necessidades do quotidiano, banalidades. E ninguém lhes dedica nenhuma atenção". Perscrutar essa história e refazer suas trajetórias num esforço genealógico significa retornar à África. Especialmente aos povos Yorubás (composto por diversas etnias que habitam regiões litorâneas e do interior da Nigéria).

A dinâmica da sociedade Yorubá é indissociável de seus mercados. Para Verger e Bastide (1992, p.145), as feiras e os mercados se constituem como instituições com capacidades simultâneas de “(...) permitir um comportamento do tipo 'capitalista' e de 'procura de lucro', e estar profundamente enraizada no comportamento tradicional, comunitário, que, ao contrário de contradizer o primeiro, contribui para a sua consolidação". Os autores (idem, pp. 128-129) distinguem quatro formas básicas de comércio ou de mercados tradicionais: 1) as grandes feiras, que acontecem de quatro em quatro dias ${ }^{5}$ nas principais cidades yorubás; 2) as pequenas feiras, que acontecem todos os dias na mesma cidade; 3) as feiras noturnas, que são extensões das pequenas feiras; 4) o comércio tradicional, realizado em esquinas, beiras de estradas e na parte externa das casas.

Imaginem, pois, a enorme e heterogênea superfície que, numa determinada região, representam todos os seus mercados elementares, uma infinidade de pequenos pontos, de transações muitas vezes medíocres. Por essas múltiplas bocas começa aquilo a que chamamos economia de troca e que se estende entre dois domínios igualmente imensos, a produção e o consumo. (Braudel, p. 23)

Portanto, na África, os mercados, as feiras, não estão dissociados da dimensão ritual e religiosa. Também são lugares de sacralidade, e para além da lógica econômica são lugares de sociabilidade. Exú é a divindade que comanda as

5 A semana yorubá possui quatro dias - Ojo Awo, dia do segredo, dedicado a Ifá e Exu; Ojo Ogun, deus do ferro, da guerra e da agricultura; Ojo Jakuta, dia de Xangô, deus do trovão; Ojo Obatala, dia de Obatalá, deus do céu. 
atividades comerciais, as relações de troca. Cada mercado possui o seu altar votivo ao deus Exú,chamado Oloojá - o dono do mercado. "E porque ele é o senhor da feira, as mulheres sempre depositam em seu altar, antes de começarem as vendas, toda sorte de oferendas (...)” (Verger, Bastide, 1992, p.142). Esta dinâmica também é encontrada no Brasil. Conta a tradição oral que o mercado municipal de Porto Alegre também possui o seu Exú protetor e sustentáculo, assentado e enterrado no solo do local. Não se sabe ao certo a sua localização, mas conta-se que não pode ser desenterrado, pois isso faria ruir a edificação. A relação existente entre Exú e as feiras e mercados públicos é essencialmente comunicacional. "Mas quem o esquece, ou não lhe faz as devidas oferendas, incorre na sua ira e ele, por ser extremamente vingativo, provocará brigas e disputas - pois é o senhor de quem está na feira - ou, então, fará as intercomunicações cessarem" (idem, p.143). Sem Exú, sem comunicação, não há venda. Sob os auspícios de Exú, o mercado configura-se como locus da comunicabilidade, da troca entre os comuns, da partilha de sensibilidades. E também do conflito, da fofoca, da intriga, das novidades da vida alheia, do conhecimento sobre os assuntos cotidianos e dos temas de interesse grupal. Portanto, da vida social em suas encenações e operacionalidades, controles e coerções. É umlocus identitário.

Por intermédio das fofocas e das brincadeiras que passam de grupo em grupo, em meio ao clamor das compras e vendas, dos risos ou das exclamações indignadas, a comunidade exerce um controle estrito sobre o comportamento dos indivíduos, sobre as transgressões passíveis dos costumes locais, sobre a vida sexual das feirantes, transformando a feira, de certa forma, no jornal falado de uma população analfabeta, lugar onde se forma e se divulga a 'opinião pública' - mas uma opinião pública a serviço da tradição. (Verger, 1992, p.148).

Don Slater reflete (a partir de Mary Douglas e Baron Isherwood) que o consumo se insere em um campo social de práticas, "o consumo enquanto fluxo de informações integra as pessoas num mundo social inteligível. Conhecimento dos códigos de consumo e participação nos rituais de consumo são essenciais para o 'projeto de criar inteligibilidade' (...)" (Slater, 2002, p.149). O mercado Yorubá é centro de cerimônias concernentes a toda comunidade. Verger e Bastide (1992, p.146) testemunham que “(...) é na feira que a moça recém-casada compra os ingredientes com os quais prepara a primeira refeição oferecida ao marido, que 
representará, de certa forma, a consagração (e consumação) do casamento”. O relato etnográfico vai ao encontro das considerações de Mary Douglas, ao analisar que “(...), o indivíduo usa o consumo para dizer alguma coisa sobre si mesmo, sua família, sua localidade.... A espécie de afirmações que ele faz depende da espécie de universo que habita" (Douglas, Isherwood, 2004, p.116).

As formas de organização dos espaços de trocas comerciais parecem elementos estruturais das sociedades humanas, ou estruturas características da longa duração. Parte-se de observações feitas no interior da Bahia (especialmente na região sul do litoral do Estado) e de Minas Gerais (nordeste do Estado, próximo ao Vale do Jequitinhonha). Estas áreas possuem forte presença de comunidades negras - como os distritos de Argolo e Helvécia, no município de Nova Viçosa (BA), povoado por descendentes de quilombolas que vivem da agricultura local e do comércio de sua produção no território e nas cidades vizinhas - , o que indica que estas formas de comércio descritas por Verger e Bastide também ocorrem ou perduram nas áreas periféricas do Brasil. Estas formas econômicas resistem, mesmo com a presença de supermercados nestes lugares, oferecendo produtos industrializados semelhantes aos encontrados nas grandes metrópoles. Braudel assinala que a configuração destas relações comerciais manifesta a passagem da produção destinada ao auto-consumo da família para o circuito do mercado, analisando que "esses mercados demarcam uma fronteira, o limite inferior da economia. Tudo o que se sirva fora do mercado apenas tem valor de uso; tudo o que cruza o seu estreito limiar adquire valor de troca" (p. 24 ). Mesmo em uma grande cidade como Salvador (BA), a feira de São Joaquim, no bairro de Água de Meninos (área portuária da cidade), é um mercado africano redivivo em terras brasileiras. Assim como o Mercadão de Madureira, no Rio de Janeiro. É lugar de compra de produtos para alimentar o corpo e a alma. Azeite de dendê, camarão seco, inhames, cabras e bodes, galos e galinhas, vasilhames de barro, ervas sagradas e medicamentosas; em suma, toda a sorte de iguarias para os deuses, e também para os homens.

A vida dos Candomblés não pode prescindir de seus mercados. É enorme a demanda dos cultos afro-brasileiros por produtos específicos para a realização das oferendas aos Orixás. "A força e a amplitude dessa presença se evidencia, sobretudo, no mercado. Revelam-se aí com toda a densidade e multiplicidade que as 
caracterizam no quadro urbano das metrópoles" (Barros, 1993, p.5-7). Insere-se neste encrave o uso esotérico (hermético) dos signos do Candomblé (como objetos de consumo ritual-religioso). O mercado possui uma dimensão na trajetória iniciática dos noviços, aspirantes à condição de membros iniciados nos mistérios do culto, pois "uma viagem ao mundo afro-brasileiro começa no mercado" (idem, p.5). A compra dos insumos necessários à realização dos ritos é ainda mais complexa, ao deparar-se com a multiplicidade de produtos africanos exigidos pelo culto. Nesse âmbito, "o conhecimento se torna importante: conhecimento dos novos bens, seu valor social e cultural, e como usá-los de maneira adequada" (Featherstone, 1995, p. 38). Na lógica do consumo primário de bens para a prática dos rituais afrobrasileiros, e no processo cognitivo intrínseco subjacente a estas atividades cotidianas das casas de Candomblé, definem-se também os percursos religiosos e pessoais dos iniciados.

(...) as compras desempenham um papel importante na própria instrução do neófito. (...) que são regidas pela etiqueta da pedagogia iniciática. (...) Comprar as coisas do ritual, mais do que uma necessidade, é uma arte. Quanto mais cedo e melhor o filho-desanto a dominar, tanto maiores serão as probabilidades de êxito em suas obrigações e, com isso, sua ascensão na hierarquia da seita. (idem, p.13).

Para os aspirantes e para os recém iniciados, o percurso das compras dos produtos para o Candomblé representa a emergência de um domínio de linguagem não apenas o jargão, gírias e dizeres específicos do povo de santo que constituem um verdadeiro patois. Deve-se considerar os usos correntes de termos na língua yorubá (falada nos terreiros tradicionais da Bahia), e também nas línguas kimbundu (falada nos terreiros de origem Angola) e ewe-fon (falada nos terreiros de origem Jêje e JêjeMahi). Existe, portanto, uma economia das trocas lingüísticas, cuja aprendizagem se constitui há algumas décadas como mercado - exemplificado pelos cursos de idiomas africanos (especialmente Yorubá), oferecidos não apenas em associações de membros do culto, mas também em universidades como a USP e a UERJ. Estas instituições conferem um novo status de saber aos membros do culto, pois são outorgantes de diplomas de axé. Desta forma, nas comunidades de Candombléé possível encontrar múltiplas recriações nos âmbitos léxico e semântico, todas resultantes de sua formação a partir de variantes lingüísticas distintas. Tais níveis lingüísticos se apresentam da seguinte maneira: 1) no português comum falado nas casas de 
Candomblé, com uso recorrente de termos regionais, de palavras populares e de termos de acepção vulgar, utilizados principalmente em situações profanas. 2) no português com forte presença semântica de expressões em yorubá, ewe-fon e kimbundu. Geralmente são utilizadas nos diálogos entre os neófitos, como numa introdução ao linguajar ritual e do cotidiano das comunidades, sejam em atividades profanas ou em preparações de rituais menos complexos. 3) no português falado pelos iniciados mais velhos, no qual predominam termos yorubá, ewe-fon e kimbundu. A utilização das formas mais africanas de falar se apresenta como reafirmação do poder dos velhos, e como forma de excluir os neófitos das conversas, considerados ainda não preparados para ter acesso a saberes mais profundos dos rituais. 4) no uso exclusivo do yorubá, do ewe-fon e do kimbundu como algo restrito aos momentos mais complexos do culto, no qual são reverenciados os deuses (Orixás, Voduns e Inquices) através de cantos, rezas e evocações.

Ao mesmo tempo que o caráter hermético do Candomblé lhe confere aspectos fortemente ocultos, secretos, misteriosos e restritos aos sacerdotes e iniciados, verifica-se uma dimensão outra, na qual configuram-se possibilidades e externalidades do culto passíveis de consumo pelos não-iniciados. Esta questão refere-se ao uso exotérico (vulgar) dos signos do Candomblé (como objetos de proteção ou amuletos, sem o sentido primário do ritual). Raul Lody observa que amuletos e, especialmente, a figa, "assumem e servem de verdadeira munição mágica para a vida do homem, no caso brasileiro, essencialmente místico, notadamente religioso, se não em complexos rituais, mas, pelo menos, em suas subjetivas e particulares devoções" (1995, p.211), que podem ser a um santo da Igreja Católica ou a um orixá cultuado no Candomblé. Os balangandãs da Bahia usados nas roupas das mulheres negras do século XIX - e que ainda hoje são utilizados pelas vendedoras de acarajé das ruas do Pelourinho - são exemplos desta passagem do amuleto de proteção ligados à lógica mágico-religiosa dos ritos afro-brasileiros para formas de uso que não necessariamente mantém o seu significado primeiro. Estes ornamentos de metal em forma de figa, fruto, animal, coração, etc., que, presos uns aos outros, formam uma penca usada pelas baianas em dias de festa, servem também como objeto decorativo, lembrança (ou, se em miniaturas, jóias ou bijuterias). As peças com finalidade de adorno ou objeto decorativo são muito encontradas nas 
lojinhas do Mercado Modelo, na capital baiana. São comuns de serem vistas na festa do Senhor do Bonfim, em Salvador, pendentes na cintura ou no pescoço das afrobrasileiras, e constituem amuleto contra o mau-olhado e outras forças adversas.

Estes trânsitos de signos e significados também podem ser vistos nas relações entre catolicismo popular e Candomblé, inserindo-se também, neste contexto, a Umbanda. No dia de São Jorge (comemorado em 23 de abril), é comum encontrar na porta das igrejas dedicadas ao santo oferendas de inhames regados a azeite de dendê - alimento votivo do deus Ogun. Também são vários os devotos que levam espadas de São Jorge para serem bentas, que é uma planta sagrada do orixá Ogun, bastante encontrada nas entradas das casas e lojas comerciais como amuleto de proteção. Proliferam-se também adesivos com a estampa de São Jorge nos vidros traseiros de automóveis que circulam pelas ruas cariocas. Em outra instância, popularizam-se as pulseiras e colares com pingentes das insígnias dos orixás nas lojas de bijuterias e joalherias - o machado duplo de Xangô, o raio de Iansã, a espada de Ogun, o leque ou o coração de Oxum, o peixe de Iemanjá, o pombo ou o opaxorô (báculo) de Oxalá, o tridente de Exú, o arco-e-flexa de Oxossi, a folha de Ossaim, a serpente de Oxumarê, dentre outros. De fato, o Candomblé está nos shopping centers.

$\mathrm{Na}$ rede de lojas de produtos naturais Mundo Verde (presente em qualquer shopping do Rio de Janeiro), encontram-se figuras dos orixás, em resina. Cabe indagar se estas representações estetizadas são capazes de encarnar os deuses além da imagem. Nos cultos africanos e afro-brasileiros, apenas a pedra - testemunha dos tempos imemoriais, anterior à existência dos homens e contemporâneas dos deuses é capaz de encarnar os orixás. Sem pedra, sem orixá. "A venda em massa de imagens religiosas como kitsch só é possível uma vez que o ícone foi despido do seu valor significante" (Olalquiaga, 1998, p.77). Em algumas lojas de artesanato e decoração sofisticadas ou alternativas, podem ser encontrados relicários fashion feitos pela artesã Ana Espinoza - com a imagem de Iemanjá (em resina), onde comumente seriam encontrados santos católicos. Pode-se dizer que estamos diante de uma manifestação explícita do kitsch, enquanto:

(...) um dos fenômenos constitutivos do pós-modernismo. As qualidades que até agora lhe foram atribuídas - canibalismo eclético, reciclagem, deleite em valores superficiais e alegóricos - 
são as mesmas que distinguem a sensibilidade contemporânea da crença anterior na autenticidade, na originalidade e na profundidade simbólica. (idem, p.73).

Tal objeto - o dito relicário - serve tão bem como peça decorativa, como pequeno altar sincrético, no qual a figura de Iemanjá convive com "adereços" (se assim podem ser chamados), como terços, crucifixo, búzio e estrelas (O Globo, Caderno Ela, 27 / 12 / 2003, p.3). Não se pode dizer que exista uma transigência no campo da etnicidade - por parte dos membros das comunidades-terreiro quanto a mercantilização de seu patrimônio sígnico, simbólico, mágico-religioso. Há uma separação clara no entendimento das pessoas da seita entre a sacralidade dos seus ritos e as apropriações da sociedade abrangente, especialmente das classes médias urbanas. Este aspecto não pode ser desprezado, pois desde o período colonial que brancos e negros articulam jogos de transigência e intransigência, tolerância e intolerância, nos campos da religião e da magia (Mello e Souza, 1994). Homens e mulheres brancos, membros das elites econômica, política e intelectual, das classes médias urbanas, sempre trafegaram no espaço dos terreiros, como território de consumo de bens simbólicos e espirituais (Santos, 2000).

A etnicidade e a diferença cultural trocaram seus valores intrínsecos pelos mais extrínsecos da permutabilidade do mercado: foi-se o tempo em que as pessoas podiam alegar convincentemente que possuíam uma cultura própria, um conjunto de práticas significativas que pudessem ser consideradas produto de um pensamento ou um estilo de vida únicos. (Olalquiaga, 1998, p.71).

Como fenômeno típico da prática da magia, são estas relações de troca numa perspectiva utilitarista, que possibilita que "clientes" e casas de Candomblé configurem uma outra instância comercial e econômica na interioridade dos terreiros. Tal trânsito, “(...) permite ao Candomblé a constituição de um fundo econômico que sustenta a infra-estrutura material do culto, da religião, e que é de propriedade privada do pai-de-santo, como um microempresário do setor de serviços, do qual ele vive, ao mesmo tempo, que é líder de uma comunidade de adeptos" (Prandi, 1991, p.196). Esta ordem de fenômenos se refere ao uso dos serviços religiosos - jogos de búzios e ebós (trabalhos e oferendas). A questão do oráculo apresenta-se como uma das principais bases de sustentação do sistema de crenças das religiões afro-brasileiras, visto que é preciso conhecer os desejos dos deuses, prever problemas e outras mazelas. Diz o provérbio yorubá que 
"as coisas não serão amanhã como são hoje. É por isso que o babalawo [pai do segredo] consulta o Ifá a cada quinto dia" (Delano, 1972, p.15). O Ifá consiste no sistema oracular ou divinatório Yorubá, comandado pelo deus da adivinhação, conhecedor do destino dos homens e da vontade dos deuses - Orumilá -, e pelo orixá e elemento comunicador Exú. Exú, "divindade mercurial africana" e primogênito da criação Yorubá, é o grande agente da comunicação, segundo esse sistema religioso. “(...) Exú é o princípio da existência diferenciada em conseqüência de sua função de elemento dinâmico que o leva a propulsionar, a desenvolver, a mobilizar, a crescer, a transformar, a comunicar" (Santos, 1993, p.131). Detentor dos epítetos de Ojixé o mensageiro -, e de Enugbarijo - a boca coletiva - , Exú é quem propicia ao homem o conhecimento da vontade dos deuses e as oferendas que deverão ser feitas para obter a sua benevolência. Portanto, é agente da relação de trocas. A noção de troca no Candomblé expressa uma das mais importantes bases litúrgicas e conceituais desta religião, na medida em que o ato devocional da oferenda implica num processo de restituição da energia (axé) e de encontro de equilíbrio. Mas também serve àqueles que, sem nenhuma relação orgânica ou iniciática com as comunidadesterreiro, desejam resolver os seus problemas mais imediatos.

É nesse contexto que o homem da metrópole conta com um instrumento a mais para suas ansiedades, seus males, seu desejo de conhecer o futuro e explicar situações que não fazem sentido: o jogo de búzios, oráculo do candomblé através do qual o babalorixá ou ialorixá desvenda mistérios e descobre os sacrifícios que devem ser feitos para resolver os problemas. (Prandi, p.190)

Ao analisar a inserção de um oráculo, oriundo de uma cultura arcaica, na lógica do mercado, não se pode apenas considerar a perspectiva das estratégias de manutenção econômica das casas de Candomblé, mas também de uma lógica de prestígio e visibilidade. Ao mesmo tempo, o sistema divinatório utilizado no Candomblé manifesta uma força ancestral e originária, cuja existência remete-se a um tempo supostamente imemorial. Nesta religião, o oráculo referencia, e referenciar-se é encontrar o sentido de ser, mesmo que este sentido tenha se tornado simplesmente material, sem nenhuma transcendência ou espiritualidade. Decerto que, entre as estratégias de visibilização do seu poder oracular, alguns babalorixás e ialorixás utilizam os meios de comunicação como esfera amplificada para a divulgação de seus talentos divinatórios - isto significa a recorrência de mais clientes 
às suas mesas de jogo de búzios. O jogo de búzios também possui a sua dimensão midiática para atingir fins mercadológicos. A Rádio Metropolitana (1090 AM - Rio de Janeiro) tem, na sua grade de programação, horários comprados por sacerdotes, que veiculam programas cujo moteé, na essência, a captação de clientes. Há revistas editadas e disponíveis em bancas ${ }^{6}$ que tratam de modo específico temas como orixás, previsões através dos búzios. Existem também outras publicações que se caracterizam pela cobertura das festas e personalidades dos terreiros, como uma espécie de colunismo social7. Um pai-de-santo da Baixada Fluminense - Josemar D'Ogun - manteve durante cerca de seis anos ${ }^{8}$ um programa sobre Candomblé na TV Bandeirantes do Rio de Janeiro. A oferta desse tipo de serviço inquieta (uma vez que se distancia bastante da prática divinatória realizada nos terreiros com fins religiosos), indicando a existência de um perfil específico do público consumidor do serviço, estratégias de marketing, discurso de atratividade e poder de geração de negócios.

A idéia de um "próprio" na cultura brasileira subentende a possibilidade de coabitação de multiplicidades em um próprio núcleo de sentido. Hoje, parece impossível pensar a cultura nacional de forma dissociada das manifestações afrobrasileiras. A imbricação entre as instâncias religiosa e secular, nas comemorações da passagem de ano na cidade do Rio de Janeiro, confere a compreensão do Candomblé como espetáculo coletivo e de dimensão festiva sacroprofana. Entre as décadas de 50 e 80 , as praias da cidade eram dos terreiros na noite de 31 de dezembro. Várias comunidades-terreiro - principalmente da Umbanda - organizavam cultos públicos nas areias de Copacabana, ao som dos atabaques e com

\footnotetext{
${ }^{6}$ Ver Revista Orixás - Candomblé e Umbanda, publicada pela Editora Minuano, São Paulo. Também as Revistas Candomblé e as Maravilhas dos Orixás, publicada pela Editora Modus, São Paulo. Revista Espiritual de Umbanda, publicada pela Editora Escala, São Paulo. Em geral, todas possuem anunciantes.

7 Uma das publicações mais significativas no Rio de Janeiro neste segmento foi o Jornal Orixás \& Africanos, editada por Adhemar D’ Omolu. Em 2006, surgiu uma nova publicação nesta mesma linha editorial, o informativo Brasil Candomblé Verdade, editado por João Batista de Ayrá. Na sua primeira página uma chamada em destaque, com fundo vermelho, anuncia: "Fazemos a cobertura jornalística da sua festa ou eventos, e a publicamos. Contacte-nos."

${ }^{8}$ O programa era produzido por Josemar Produções e foi veiculado na TV Bandeirantes do Rio de Janeiro, aproximadamente entre o mês de março de 1999 até novembro de 2005; porém com algumas interrupções.
} 
manifestações de entidades, mas tendo como grande homenageada Iemanjá - A Rainha do Mar. A partir da primeira gestão do prefeito César Maia (iniciada em 1993), a instalação dos terreiros nas areias de Copacabana foi proibida, sendo banidos para as poluídas águas da Baía da Guanabara (mais especificamente na Praia da Bica, Ilha do Governador). Mesmo assim, a festa também rememora os antigos ritos de renovação, ainda que re-significados, cujo elemento principal é a água. Como fenômeno típico da cultura brasileira, o revéillon carioca é a mescla de manifestações entre as nossas heranças culturais africanas e as apropriações urbanas e pósmodernas. Lançar flores ao mar e pular sete ondas nesta data adquirem uma expressão daquilo que não necessariamente se sabe o sentido, mas que se entende como fundamental para a garantia de felicidade no ano vindouro. Há uma diversidade de apropriações de signos que manifestam este desejo como mensagem ritual do que se espera - as flores para agradar a divindade do mar, o champagne, as roupas brancas ou nas cores do orixá regente do ano que se aproxima, peças íntimas nas cores indicadas (vermelha para quem quer sexo, amarela para quem procura dinheiro e prosperidade, rosa para quem deseja o amor, branca para quem busca a paz). “A experiência está disponível, sobretudo através de signos: as coisas não são vividas diretamente e sim por um intermediário, no consumo das imagens e objetos que substituem aquilo que representam" (Olalquiaga, 1998, p.71).

O consumo supõe a manipulação ativa de signos. Subentende-se, portanto, que esta junção de signo e mercadoria na sociedade capitalista pós-moderna produziu a mercadoria-signo (Featherstone, p.33). Para além das festividades do revéillon no Rio de Janeiro, as mercadorias-signo oriundas do Candomblé estão cada vez mais disseminadas na moda. Constitui-se, cada vez mais, no adorno e vestuário, o uso estético dos signos do Candomblé na moda. Ao serem descolados da dimensão ritual-religiosa, tais signos ficam livres para assumir um valor de uso secundário, puramente estético. "A autonomia do significante, mediante a manipulação dos signos podem ficar independentes dos objetos e estar disponíveis para uso numa multiplicidade de relações associativas" (idem). Os desfiles da griffe M. Officer, nos eventos da São Paulo Fashion Week e do Rio Fashion Week, especialmente no ano de 2003, foram emblemáticos por tomarem como tema o Candomblé para a criação das coleções. "A homogeneização dos signos e a ampla 
circulação de bens de consumo tornam todas as culturas suscetíveis a essa apropriação, e quanto mais parecerem imbuídas de intensidade emocional, tanto melhor" (Olalquiaga, 1998, p.72). No discurso do estilista Carlos Miéle, criador da coleção e proprietário da marca, apregoa-se o intuito de exibir um Brasil "real" e a nossa diversidade religiosa. Se a "ligação entre as imagens religiosas e o kitsch baseia-se no caráter dramático de seus estilos, cuja função é evocar sem ambigüidade, dissipando toda a ambivalência e a abstração" (idem), há casos em que se busca contextualizar culturalmente as apropriações. A mostra "Candomblé" realizada na Clube Chocolate, loja localizada num dos endereços sofisticados de São Paulo (na rua Oscar Freire), parece ter se preocupado em conferir uma dimensão cultural e mais orgânica ao evento.

Foi em meio aos batuques de Carlinhos Brown, à cantoria de mãesde-santo e às imagens dos deuses do candomblé, que as badaladas modelos mostraram a nova coleção da M. Officer, que pouco tinha a ver com o inverno. (...) Fugindo das regras, Carlos Miéle, o criador da grife, diz que quis mostrar o que o Brasil tem de real e por isso escolheu o candomblé como tema, que foi marginalizado durante muito tempo. (ISTOÉ, No 1748, em 02 / 04 / 2003)

A mostra "Candomblé", em cartaz na Clube Chocolate desde sexta (01.07), homenageia a religião dos orixás com fotos, esculturas, roupas, acessórios, jóias e livros ligados ao tema. Participam da mostra o fotógrafo Pierre Verger [falecido em 1996] e a escultora Tati Moreno. O mais incrível são as vestimentas dos 16 orixás expostos na praia, dentro da loja da Oscar Freire. Os curadores encomendaram ao Pai Flávio de Iansã peças produzidas em seu terreiro para a ambientação da loja, para criar uma atmosfera mais próxima ao universo do Candomblé. A loja apresenta ainda uma pesquisa com ervas, especiarias, frutas e flores presentes nos rituais do Candomblé. A Clube Chocolate fica à rua Oscar Freire, 913, Jardins. (www.ericapalomino.com.br, em 06.07.2005).

Se o Candomblé é fonte de signos para a produção de bens de consumo materiais e simbólicos na moda e na cultura, há adeptos da seita que se afirmam a partir de códigos de consumo de bens de valor elevado. O babalorixá Augusto César é um dos exemplos de consumo conspícuo no meio religioso afro-brasileiro. Em entrevista ao site da revista Oi (matéria intitulada: Pai-de-Santo Grifado), o sacerdote, famoso pelas suas relações com socialites, artistas, políticos e celebridades, expõe seus hábitos de consumo. Declarações como: “Adoro champanhe. Veuve Clicquot é a minha predileta. A gente deve ter sempre uma caixa de champanhe na geladeira, porque há sempre um bom motivo para comemorar”. "Adoro jóias. Acho 
Cartier o máximo." "Já fui inúmeras vezes a Paris. Lá tem todas as coisas de que gosto: perfume, boa comida, obras de arte”. Em 27 de dezembro de 2003, Augusto César também foi objeto de matéria no Caderno Ela do Jornal O Globo (p.5), intitulada "Babalorixá do Luxo". Na entrevista, o pai-de-santo reitera sua predileção por Paris: "Eu adoro o chique da cidade. A louça Limoges... Imagina fazer as coisas para o santo com Limoges? E o cristal Baccarat? É tudo.” O encontro com a sociedade de consumo, na perspectiva da competição pelas estruturas de gosto e pelo poder social, é dispositivo de estabelecimento das distinções entre os membros da classe sacerdotal do Candomblé que também define e transforma o habitus.

O Candomblé como fonte e inspiração da produção cultural - na produção acadêmica, literária, nos manuais de prática religiosa, na música e nas artes plásticas - não é um fenômeno recente. Os rituais afrobrasileiros foram fonte de inspiração para a pintura de Carybé, as teses acadêmicas de Arthur Ramos, Edison Carneiro e Roger Bastide (e toda a sua geração de descendentes acadêmicos), os romances de Jorge Amado e Antônio Olinto, a fotografia e as pesquisas etnográficas de Pierre Verger, a escultura de Rubem Valentim e de Mário Cravo, a música de Vinícius de Moraes, o canto de Clara Nunes, dentre tantos outros. Há, neste breve apontamento, uma mudança qualitativa, da inserção do Candomblé na cultura brasileira e também na indústria cultural. Por várias décadas - dos fins do século XIX ao início do XX - os terreiros pontilhavam as páginas criminais dos jornais, numa medonha exibição de fiéis aprisionados e objetos apreendidos pela truculência policial. Ao mesmo tempo, João do Rio (Paulo Barreto) transformava estes negros e seus terreiros em crônicas para a leitura da elite letrada do Rio de Janeiro do início do século. Décadas mais tarde, a mídia irá se apropriar ainda mais desta mesma expressão religiosa. É importante lembrar o pai-de-santo Joãozinho da Goméia e suas filhas de santo na Radio Commercial da Bahia em 1936, nas atividades preparatórias para o Congresso Afro-Brasileiro de 1937, organizado por Edison Carneiro; e, anos mais tarde, nas páginas do Jornal do Brasil e do Pasquim nos anos 70. Ou ainda, o costureiro Denner na sua iniciação (que foi transformada em acontecimento de mídia), nas páginas fartamente ilustradas da revista Manchete. Ao prosseguir nesta breve história das Religiões Afro-Brasileiras nos meios de comunicação não se pode esquecer do rádio, de Átila Nunes e de 
Bambina Bucci, portando a bandeira da Umbanda. Do Exú "Seu 7 Rei da Lira", sempre presente nas emissoras de TV nos anos 70 (nos programas de Chacrinha e de Flávio Cavalcanti) - um dos marcos na guerra da audiência na TV brasileira, muito antes de Gugu Liberato e Fausto Silva. A imagem de Clara Nunes cantando "Guerreira" no Fantástico no início da década de 1980, com as cataratas de Iguaçu ao fundo. Ainda estão presentes os jogos de búzios e de cartas por telefone na década de 1990, com Marlene Deon, Katja Bastos e sua tribo cósmica, e também de Walter Mercado e o seu "Ligue djá!". E as previsões catastróficas de Mãe Dinah em 1996, "quase reivindicando a autoria da morte" dos Mamonas Assassinas? Parece claro o velho princípio do liberalismo: "se há oferta é porque há demanda". É ainda recorrente observar que esta demanda se dá pela espetacularização, pelo interesse num Candomblé enquanto exótico; expressão da beleza, do diferente e do estético, objeto de exoterização. Esta apropriação pelo caráter exótico da seita, sem a existência de vínculos orgânicos que estabeleçam os laços sagrados com as religiões afro-brasileiras, é visível na proposta do músico Otto. Em seu CD Condom Black, lançado em 2001, o artista se propõe a fazer um "terreiro eletroacústico". No entanto, desconhece os rituais, nem tampouco freqüenta terreiros.

Mais do que uma questão de fé, o candomblé entra na mistureba de Otto como base musical. 'Não tenho a clareza da celebração afrobrasileira, não freqüento terreiros', diz o compositor. 'Entretanto, a influência está na minha vida o tempo todo, no jeito como falo, na minha maneira de compor. Faço um candomblé freestyle, não cheguei a pegar literalmente os temas e a percussão dos terreiros só meti a mão, toquei e pronto, seja o que Deus quiser. Acho que a principal influência está no jeito em que componho, sempre abordando a natureza. Isso eu aprendi com a música do candomblé, que celebra as forças naturais', afirma. (www.clickmusic.com.br)

Outro fenômeno já anteriormente identificado foi o surgimento - na década de 90 - dos serviços telefônicos através das linhas $0900^{9}$, criadas pelo porto-riquenho Walter Mercado, para consultas astrológicas, com os búzios, e com as cartas do tarot ou do baralho cigano. Fenômeno este que se pode classificar como uma "exoterização

\footnotetext{
9 Walter Mercado deixou o mercado brasileiro em 1998, com a proibição das linhas 0900. Esotéricos brasileiros como a astróloga Marlene Deon, a vidente Mãe Dinah, dentre outros, também exploraram as linhas 0900 para o oferecimento de serviços de consultas místicas, incluindo o jogo de búzios.
} 
do Candomblé"10. Cabe definir estas práticas no campo do consumo telemático dos produtos e serviços oferecidos pelo Candomblé - por canais telefônicos, televisuais e virtuais de comunicação e compra de produtos e oferta de serviços. Parece muito sintomático que na rede se comercialize o "shampoo exotérico", juntamente com o "kit orixás", e também consultas aos búzios respondidas via e-mail, telefone ou webcam, com múltiplas formas de pagamento tais como depósito bancário ou cartões de crédito Visa, Diners ou Mastercard ${ }^{11}$. Mike Featherstone (idem, p.32) observa que:

A fase atual, de oferta excessiva de bens simbólicos nas sociedades ocidentais contemporâneas, e as tendências para a desclassificação e desordem cultural (que alguns rotulam de pós-modernismo) estão, portanto, pondo em evidência as questões culturais e têm implicações mais amplas em nossa conceituação do relacionamento entre cultura, economia e sociedade.

Ao falar de Candomblé na perspectiva da cultura de consumo, da virtualidade e das indústrias culturais, reafirmam-se também a questão do esvaziamento ontológico dos símbolos; fala-se de uma nova instauração e que sugere algo que é da ordem econômica, da produção e da circulação de bens de consumo e dos discursos que deles provém. O percurso destas análises e considerações permite constatar que o Candomblé, ao ser inserido e se inserir na cultura de consumo, relaciona-se com a expansão da produçãocapitalista de mercadorias. Tal aspecto se manifesta tanto pela lógica do consumo endógeno (no interior do culto, no consumo ritual) quanto exógeno (na externalidade do culto, pelo consumo das imagens e signos, fora da religiosidade). Também está ligado ao fato de que o uso das mercadorias e o trânsito pelo espaço dos mercados de produtos religiosos servem para criar vínculos e estabelecem distinções sociais no seio do culto, dentro da

\footnotetext{
${ }^{10}$ Esta questão foi mais amplamente desenvolvida em: SANTOS, Cristiano H. R. "Candomblé na Internet: uma Cultura de Arché na Virtualidade. pp. 55-61. In Novas Tecnologias: Comunicação, Imaginário, Virtual e Social. Logos: Comunicação \& Universidade ( $\left.{ }^{0}{ }_{14}\right)$. Rio de Janeiro: UERJ, $1^{\circ}$ semestre de 2001.

${ }^{11}$ A relação de cartões de crédito aceita pela Sociedade Beneficente Cultural Africana Ilê Oxum Docô, pelos serviços de tarot online, búzios online e tele consulta está no conteúdo disponível em: http://www.oxum.com.br/teleconsulta.asp. Acesso em: 10 / 05 / 2002. Diz o site: "A tele consulta pode ser feita com o jogo de cartas, búzios ou tarot através do telefone. O pagamento é efetuadoatravés de débito no seu cartão de crédito (VISA, CREDICARD, DINNERS ou AMERICAN EXPRESS) ou por um depósito antecipado à consulta."
} 
perspectiva da ascensão iniciática. Na dinâmica do consumo de produtos da diversidade cultural na pós-modernidade, o Candomblé também se insere como fonte da produção de bens simbólicos e materiais na indústria da moda e do entretenimento. Nesse sentido, integra-se ao sistema de práticas sociais, como matriz sígnica de "prazeres emocionais do consumo, sonhos e desejos celebrados no imaginário cultural consumista" (Featherstone, 1995, p.31). Para compreender este conjunto de processos, de significados, esta profusão de manifestações culturais, é fundamental retornar a um conceito - sincretismo cultural. Para Canevacci (1996, p.13), o sincretismo cultural é “(...) termo-chave para a compreensão da transformação que está se dando naquele processo de globalização e localização que envolve, transforma e arrasta os modos tradicionais de produção de cultura, consumo, comunicação".

No entanto, a fusão e reinterpretação de elementos culturais diversos, na lógica da sociedade de consumo, podem significar apenas a apropriação estética, sem necessariamente a produção do novo. Porém, em meio à floresta globalizada de signos e de significantes destituídos de significados, um princípio permanece: o sagrado e a religião que pressupõe as mediações entre homens e orixás e o vínculo comunitário que media a relação entre os membros do Candomblé. 


\section{Referências:}

BARROS, José Flávio Pessoa de et alli. A Galinha D’ Angola: Iniciação e Identidade na Cultura Afro-Brasileira. Rio de Janeiro: Pallas, 1993.

BRAUDEL, Fernand. Dinâmica do Capitalismo. Lisboa: Editorial Teorema, 1985.

CANEVACCI, Massimo. Sincretismos: Uma Exploração das Hibridações Culturais. São Paulo: Studio Nobel, 1996.

DELANO, Isaac. Òwe L'Esin Oro: Yoruba Proverbs - Their Meaning and Usage. Ibadan: Oxford University Press, 1972.

DOUGLAS, Mary, ISHERWOOD, Baron. O Mundo dos Bens: Para uma Antropologia do Consumo. Rio de Janeiro: UFRJ, 2004.

FEATHERSTONE, Mike. Cultura de Consumo e Pós-Modernismo. São Paulo: Studio Nobel, 1995.

LODY, Raul. O Povo do Santo. Rio de Janeiro: Pallas, 1995.

MELLO E SOUZA, Laura. O Diabo e a Terra de Santa Cruz. São Paulo: Companhia das Letras, 1994.

SODRÉ, Muniz. Claros e Escuros: Identidade, Povo e Mídia no Brasil. Petrópolis: Editora Vozes, 1999.

SODRÉ, Muniz. A Verdade Seduzida: Por um Conceito de Cultura no Brasil. Rio de Janeiro: Francisco Alves, 1988.

OLALQUIAGA, Celeste. Megalópolis: sensibilidades culturais contemporâneas. São Paulo, Studio Nobel, 1998.

PÓVOAS. Ruy do Carmo. A Linguagem do Candomblé. Rio de Janeiro: José Olympio Editora, 1989.

PRANDI, Reginaldo. Os Candomblés de São Paulo. São Paulo: Hucitec, Edusp, 1991.

SLATER, Don. Cultura do Consumo e Modernidade. São Paulo: Nobel, 2002.

SANTOS, Cristiano H. R. dos. "Candomblé". In SAWYER, John F. A. SIMPSON, J. M. Y. The Concise Encyclopedia of Language \& Religion. Oxford (UK): Pergamon / Elsevier Science, 2001. pp. 20-21.

SANTOS, Cristiano H. R. dos. "Candomblé, Mídia e Poder - A Trajetória do Babalorixá Joãozinho da Goméia”. In IX Simpósio Regional: História, Memória e Comemorações - Caderno de Resumos. Niterói (UFF): ANPUH / RJ, 2000, p. 282.

SANTOS, Juana Elbein. Os Nàgô e a Morte: Pàde. Àsèsè e o Culto Égun na Bahia. Petrópolis: Editora Vozes, 1993.

SILVA, Vagner Gonçalves. Orixás da Metrópole. Petrópolis: Editora Vozes, 1995.

VERGER, Pierre, BASTIDE, Roger. "Contribuição ao Estudo dos Mercados Nagô do Baixo Benin”. In VERGER, Pierre. Artigos (Tomo I). Salvador: Currupio, 1992. 


\section{Internet}

http://www.erikapalomino.com.br

http://www.revistaoi.com.br/nova/augusto_cesar.asp 